\title{
The Evolutionary Ecology of Arctic Fishes
}

\author{
by David Cameron Hardie
}

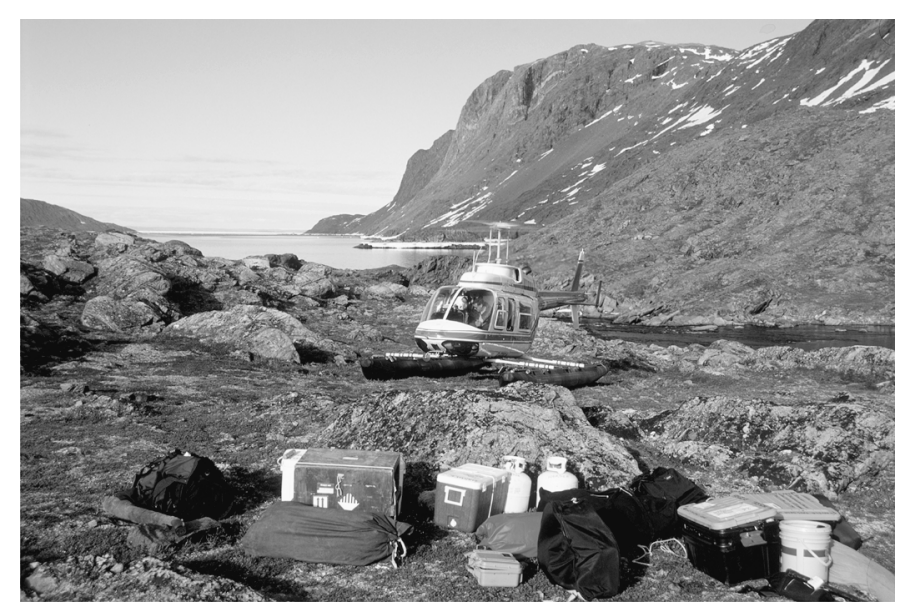

Helicopter deposits field gear at Ogac Lake, Nunavut, July 2003. (Photo: D. Hardie.)

\section{INTRODUCTION}

$\mathrm{T}$ Ihe northern oceans, Canada's largest marine environment, are undergoing disquieting changes in habitat and climate. Nonetheless, northern oceans have received limited attention from researchers, while work has focused on more hospitable, accessible, and economically important systems in the south. In fact, very little is known about the cold-water fishes of polar waters. Yet these environments exert pressures on life unlike any other, molding unique and remarkable fish communities that display fascinating adaptations to their frigid settings. The general focus of my research is to identify genetic, ecological, and life history adaptations among Arctic marine fishes. The research can be divided into two main sections. The first concerns the life history and general biology of noncommercial Arctic marine species. The second examines the populations of Atlantic cod that persist in Arctic lakes well to the north of their current distribution in Canadian marine waters.

From a geographic perspective, Canada is indisputably a polar nation. The terrestrial Canadian Arctic contains $20 \%$ of Canada's freshwaters and about $38 \%$ of its land area, some 3.8 million $\mathrm{km}^{2}$ spanning 23 degrees of latitude and 81 degrees of longitude. Moreover, the Canadian Arctic Ocean boasts a coastline stretching some $173000 \mathrm{~km}(71 \%$ of Canadian total) and an area of 3.2 million $\mathrm{km}^{2}$ (67\% of Canadian coastal waters), dwarfing both its eastern and western counterparts (Reist, 1997). While temperatures, particularly in the marine environment, are perennially low and essentially stable, extreme seasonal oscillations in light result in high variability in primary productivity and energy supply (Power, 1997). Despite these ostensibly severe and variable conditions, aquatic environments offer protection from the extreme Arctic climate and are home to a quarter of Canada's total fish species (224 marine species, or $27 \%$, and 42 freshwater species, or $23 \%$, of the total; Reist, 1997). Since most knowledge about Arctic fishes derives from research related to development, species of no cultural or commercial importance have received little or no attention. Thus a focused effort to advance knowledge of the biology of noncommercial Arctic marine fishes is long overdue. The populations of Atlantic cod in coastal Arctic lakes, considered to be "of special concern" by the Committee on the Status of Endangered Species in Canada, present a fascinating opportunity to study a well-known species in a highly unusual environment at the extreme edge of its range.

\section{LIFE HISTORY ADAPTATIONS AMONG NONCOMMERCIAL ARCTIC MARINE FISHES}

In general, my research concerns the adaptations of Arctic fishes for survival in their unique environment, with a particular focus on life history traits. The study of life history is fundamental to biology, since an organism's fitness is tightly linked to life history parameters (Stearns, 1992). The principal life history traits - size at birth; growth pattern; age and size at maturity; number, size, and sex ratio of offspring; age- and size-specific reproductive investments; age- and size-specific mortality schedules; and length of life-are unknown for most Arctic fish species. The study of life history is based on the premise that trait combinations are constrained by trade-offs among traits (Roff, 2002). In my research, I will examine how these trade-offs relate to the demands and limitations of Arctic aquatic environments. How fast do Arctic fishes grow, and at what age/size do they mature? How long do they live? How frequently do they reproduce throughout their lifetime? Do they produce many small offspring, or only a few large ones? Do they provide care for them? What are the costs of reproduction at different ages? Answers to these questions will be valuable on several levels. Clearly, they will have fundamental biological importance: since life history traits are primary determinants of population dynamics, their study is elemental to both theoretical ecology and resource management (Winemiller and Rose, 1992). Furthermore, variability in life history characters is among the most fundamental ways in which organisms adapt to environmental pressures (Schaffer and Elson, 1975). In a comparative context, this work will allow me to evaluate whether Arctic fishes are fundamentally or qualitatively different from 


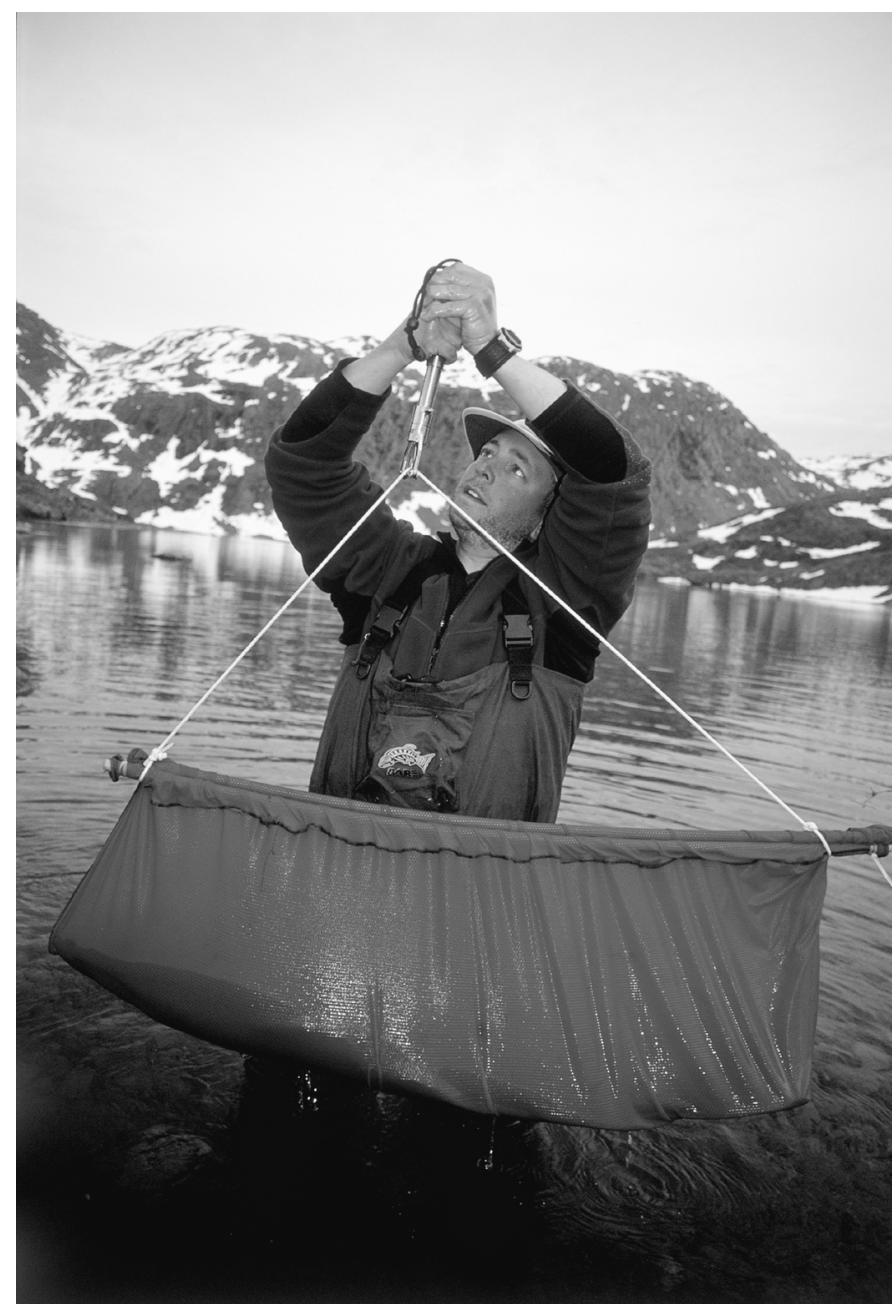

Weighing large cod in a "cradle," Ogac Lake, Nunavut, July, 2003. (Photo: D. Hardie.)

related taxa living in more southern waters, an important factor in understanding the evolution of fishes in coldwater settings.

Apart from a small number of specimens obtained in the past by scuba diving, I have not yet obtained specimens of noncommercial Arctic marine species at the time of this writing. However, an opportunity to work aboard a research trawler fishing for turbot in Davis Strait in the fall of 2003 promises to provide a great diversity of specimens for future study. This work will consist primarily of collecting basic biological data, such as distribution, length, weight, age, growth rate, sex, age at maturity, size at maturity, and fecundity. On a practical level, these data will address gaps in our knowledge about the biology of Arctic fishes and will be useful in identifying potential sensitivities to various natural and anthropogenic impacts in the North. Furthermore, I will seek to understand how certain combinations of life history traits help Arctic fishes to cope with the unusual demands of their extreme environment and consider how these combinations compare to those found in related taxa in warmer waters, for which data collection is ongoing in our laboratory.

\section{ATLANTIC COD IN LANDLOCKED ARCTIC FIORDS}

Landlocked populations of Atlantic cod (Gadus morhua) are known from three coastal lakes in Frobisher Bay (Ogac Lake) and Cumberland Sound (Qasigialiminiq and Tariujarusiq Lakes). These populations are remarkable on several levels, yet are very poorly understood. Not only are they at the northern extreme of the species' range, but they also persist in an unusual habitat. Although levels of traditional harvest of these populations have not been formally documented, exploitation was low historically, but has intensified recently in some cases. Current knowledge suggests potential sensitivity to exploitation (Patriquin, 1967; Lewis, 1989), which is particularly significant given that most marine stocks of this species have been depleted or extirpated. The objectives of this part of my research include the study of (i) basic physical, chemical, and biotic characteristics of Arctic lakes in which Atlantic cod occur, and (ii) aspects of these populations' biology, life history, and genetics.

Ogac Lake was intensely studied during 1957, 1962, and 1965 by Dr. I.A. McLaren (McLaren, 1961, 1967a, b, 1969a, b; Patriquin, 1967). This work characterized Ogac Lake as meromictic, having a freshwater layer at its surface, with a deeper saline layer of almost full-strength seawater extending from approximately 3 to $30 \mathrm{~m}$, and a hypersaline, anoxic layer at its bottom. The lake contains a simplified community of marine organisms that either persist as truly landlocked forms or are carried into the lake on the highest spring tides, which contribute seawater monthly during the open-water season. McLaren's work also provided the samples and data for the only peerreviewed study of the cod in Ogac Lake, which found that this population was small, consisting of a breeding population of only about 500 individuals (Patriquin, 1967). The cod were found to exhibit a high degree of cannibalism, to vary considerably in growth rate, and to mature at a remarkably large size and advanced age. In fact, the size and age at maturity reported in Ogac Lake were the highest ever recorded for the species. Some genetic information was provided in an M.Sc. thesis from Dalhousie University (Brooker, 1994), and an internal report of the Iqaluit office of Fisheries and Oceans Canada provided population age and size structure data for Atlantic cod from Qasigialiminiq Lake (Lewis, 1989). Several popular accounts of the "cannibal cod" of Ogac Lake have also been published (Kennedy, 1953; Bruemmer, 1966). Before my fieldwork in 2003, Tariujarusiq Lake had never been studied.

\section{Methods}

Field camps were established for about two weeks at each of Ogac, Qasigialiminiq, and Tariujarusiq Lakes during July and August 2003. Data on the length, weight, sex, maturity, liver weight, gonad weight, and stomach contents were collected from 100 cod from each lake. 


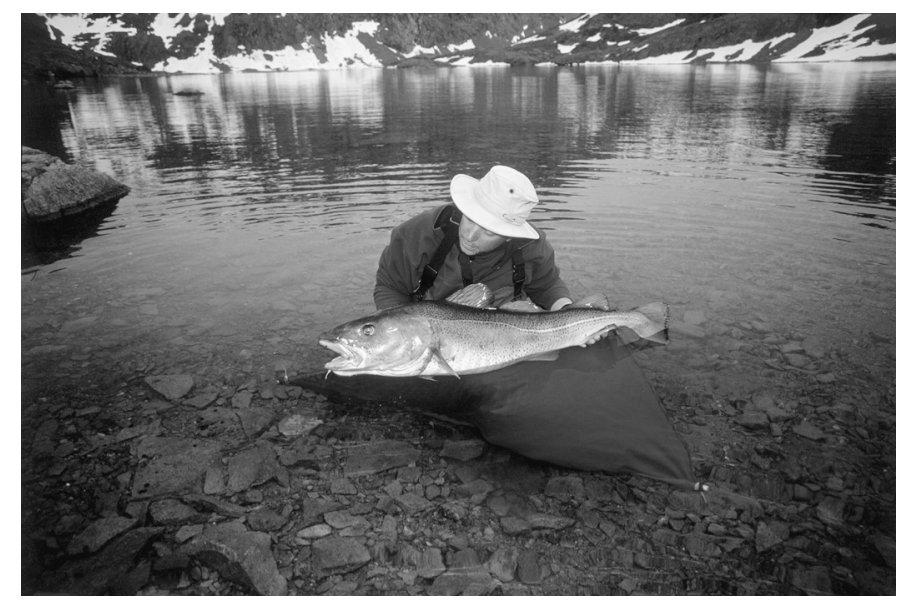

Tag release of large cod, Ogac Lake, Nunavut, July 2003. (Photo: D. Hardie.)

Tissue samples and otoliths were also collected for genetic and age/growth analysis, respectively. Underwater video was used to qualify benthic macrofauna and to observe cod behaviour and movement in all three lakes. Plankton tows were made as described by McLaren (1969a) to compare micro-invertebrate populations of the three lakes and compare the present population of Ogac Lake to that described by McLaren for 1957-65. Bathymetric measurements by sonar were taken across a number of transects in both Qasigialiminiq and Tariujarusiq Lakes to compare them to Ogac Lake, where the bathymetry is known from McLaren (1967b). Salinity, temperature, and dissolved oxygen strata were measured in each basin of each lake, again to compare abiotic limnology across lakes and over time at Ogac Lake. Temperature data loggers were deployed near the outflow of each lake to measure the timing and frequency of tidal inflow during high spring tides.

\section{Preliminary Results}

Although much work remains to be done, some preliminary results have been compiled. Like Ogac Lake, Qasigialiminiq and Tariujarusiq Lakes are salt meromictic lakes, although they are warmer than Ogac Lake at all depths, and surface salinity is higher at Tariujarusiq $(7 \% o)$ than at the other two lakes $(<1 \%$ ). One notable difference is the absence of sea urchins from Qasigialiminiq Lake and their predominance in the benthos (and cod stomach contents) in Tariujarusiq Lake. Cannibalism appears to be less frequent in the Cumberland Sound lakes ( 14\%) compared to Ogac Lake $(\sim 35 \%)$. Cod in all three lakes mature at a large size, as previously reported for Ogac Lake (Patriquin, 1967). Our results confirmed that female cod in these lakes do not reach maturity until they are longer than $60 \mathrm{~cm}$, which is the largest reported size at maturity throughout the range of this species. Preliminary microsatellite DNA analysis at eight loci has revealed that cod in Ogac Lake exhibit remarkably low genetic variation compared to other Northwest Atlantic cod populations, which is consistent with Brooker's (1994) report of low allelic variation in this population compared to that of marine stocks. Furthermore, these data confirm Patriquin's (1967) estimate that the population of cod in Ogac Lake is small: only hundreds of adult individuals. Genetic analyses of samples from Qasigialiminiq and Tariujarusiq Lakes are ongoing, but they are expected to reveal similar results.

\section{Future Work}

The completion of microsatellite DNA analysis for all three populations will conclude our comparisons of genetic variability and divergence, both among these landlocked populations and between these populations and marine cod stocks. We will then explore how long these populations have been isolated and from what marine stock they derive. This last point is particularly interesting, given the current absence of Atlantic cod from adjacent marine waters and the unique genetic features that these landlocked populations seem to exhibit despite the relative immaturity of this recently deglaciated area. The recovery of data from temperature loggers will reveal the frequency of tidal influence on these lakes, which, coupled with estimates of rates of isostatic rebound, will allow us to project expected rates of change in these lakes. Plankton abundance and species composition, as well as temperature, oxygen, and salinity profiles, will be compared both among these lakes and to the corresponding data collected by McLaren in his initial studies.

Once age and growth data have been obtained from otolith analysis, we will attempt to relate variability in these features within and among the populations to biotic and abiotic differences among lakes. For example, cannibalism may be the only way for cod in these lakes to attain high growth rates or maturity. How do growth rates and age/size at maturity compare to differences in the degree of cannibalism among lakes? These questions could be explored further by separating genetic from environmental influences on growth rate and age or size at maturity, although this work will not be simple. In order to achieve this, we will attempt to return cod larvae to the laboratory for inclusion in an ongoing common-garden experiment on temperate marine stocks of this species. If we are successful, we will be able to study whether phenotypic peculiarities of landlocked Atlantic cod persist under standardized conditions.

\section{SUMMARY}

Despite a serious dearth of scientific knowledge, polar settings, with their distinctive dichotomy of stable and variable features, provide an interesting forum for studying the evolutionary ecology of fishes. These features predict unique life history trait combinations, which may be important determinants of resilience to extreme and changing Arctic environments. The genetic and environ- 
mental bases of life history plasticity and trade-offs are of particular interest in the context of the immaturity of Arctic environments, which are in a state of flux, both natural and anthropogenic. The striking simplicity of some Arctic communities affords good opportunities for comprehensive study of species in relatively intact natural settings. In the case of landlocked Atlantic cod, we can study a species of significant conservation concern persisting at the biotic and abiotic extremes of its range.

\section{ACKNOWLEDGEMENTS}

This work is supported by NSERC, Dalhousie University, the Mountain Equipment Cooperative Environment Fund, the Polar Continental Shelf Project (Project \#607-03), the Nunavut Research Institute, the Royal Canadian Geographical Society, the Arctic Institute of North America, and Fisheries and Oceans Canada. We would also like to thank the Amarok and Pangnirtung Hunters and Trappers Organizations for their support and assistance. S. Courchesne, M. Mipeegaq, A. Alikatuktuk, and L. Ishulutak, as well as N. and D. Sowdluapik, provided valuable field assistance. Lastly, I would like to thank my supervisor, Jeff Hutchings, for his help and enthusiasm in meeting the scientific and logistical challenges of this research.

\section{REFERENCES}

BROOKER, A.L. 1994. Polymorphic microsatellites: Tools for measuring genetic diversity in subpopulations of Atlantic cod (Gadus morhua). M.Sc. thesis, Dalhousie University, Halifax, Nova Scotia.

BRUEMMER, F. 1966. Baffin's landlocked cod. Canadian Geographic 72(5):180-183.

KENNEDY, C. 1953. Cannibal cod in an Arctic lake. Natural History 62:78-82.

LEWIS, T. 1989. Information Report: Atlantic cod (Gadus morhua) in Nettilling Fjord, Baffin Island, 1985-1986. Iqaluit, Nunavut: Fisheries and Oceans, Eastern Arctic Area.
McLAREN, I.A. 1961. The hydrography and zooplankton of Ogac Lake, a landlocked fiord on Baffin Island. Fisheries Research Board of Canada Manuscript Report Series No. 709. 1967a. Introduction to biological studies of Ogac Lake, a landlocked fiord on Baffin Island. Journal of the Fisheries Research Board of Canada 24:975-980.

. 1967b. Physical and chemical characteristics of Ogac Lake, a landlocked fiord on Baffin Island. Journal of the Fisheries Research Board of Canada 24:981 - 1015.

- 1969a. Population and production ecology of zooplankton in Ogac Lake, a landlocked fiord on Baffin Island. Journal of the Fisheries Research Board of Canada 26:1485-1559.

- 1969b. Primary productivity and nutrients in Ogac Lake, a landlocked fiord on Baffin Island. Journal of the Fisheries Research Board of Canada 26:1561-1576.

PATRIQUIN, D.G. 1967. Biology of Gadus morhua in Ogac Lake, a landlocked fiord on Baffin Island. Journal of the Fisheries Research Board of Canada 24:2573-2594.

POWER, G. 1997. A review of fish ecology in Arctic North America. American Fisheries Society Symposium 19:13-19.

REIST, J.D. 1997. The Canadian perspective on issues in Arctic fisheries management and research. American Fisheries Society Symposium 19:4-12.

ROFF, D.A. 2002. Life history evolution. Sunderland, Massachusetts: Sinauer Associates Inc.

SCHAFFER, W.M., and ELSON, P.F. 1975. The adaptive significance of variations in life history among local populations of Atlantic salmon in North America. Ecology 56:577-590.

STEARNS, S.C. 1992. The evolution of life histories. Oxford: Oxford University Press.

WINEMULLER, K.O., and ROSE, K.A. 1992. Patterns of lifehistory diversification in North American fishes: Implications for population regulation. Canadian Journal of Fisheries and Aquatic Science 49:2196-2218.

David Cameron Hardie is this year's winner of the Lorraine Allison Scholarship. He is currently enrolled in the doctoral program of the Department of Biology at Dalhousie University in Halifax. 